\title{
エキシマレーザを用いた生体材料の 3 次元加エによる 神経ネットワーク埋め込み技術の開発 \\ Development of the Neuronal Network Embedding Techniques by Three-dimensional Processing of the Biomaterials Using an Excimer Laser
}

\author{
鈴木 郁郎 (正会員), 天野 翔太(非会員), 小田原 あおい(学生会員), 後藤 正男 (非会員)
}

Ikuro Suzuki, Shota Amano, Aoi Odawara, Masao Gotoh

\begin{abstract}
Micropatterning methods using three-dimensional (3D) substrates or scaffolds that reproduce aspects of the in vivo microenvironment could facilitate the engineering of functional tissues for transplantation or more robust experimental models. Cell embedding techniques into 3D scaffolds can be expected for applications such as (1) three-dimensional culture technique mimicking the structure of living tissue closely, (2) efficient differentiation of stem cells, and (3) implantation of biocompatible materials-contained cell. In this study, we focused nerve cells and developed a neuronal network embedding method into 3D scaffolds using an excimer laser that precisely etches the 3D biomaterials. It was then possible to guide neural network formation in laser etched area. Using excimer laser, we succeeded in etching collagen fibers at minimum processing $5 \mu \mathrm{m}$ in width and culturing Rat hippocampal neuronal networks in laser processing area. In addition, we demonstrated that neuron elongates neurites into the hole that has been processed to the Z-axis. This excimer laser etching in $3 \mathrm{D}$ scaffold is useful as cell arrangement technology to the biocompatible material depths.
\end{abstract}

\section{Key Words}

Excimer laser, Micro Fabrication, Collagen fiber, Neuronal network, 3D

\section{1. はじめに}

細胞から組織を人工的に 3 次元再構成する技術は, 再生医療 における移植組織や動物実験を代替する薬剤評価組織への応 用が期待されている. ヒ下人工多能性幹細胞 (hiPS 細胞)の樹立, および大量培養系の構築により, 様々な組織において 3 次元培 養技術の開発が期待されるようになった. 組織構造を模倣する 3 次元培養技術の開発は, その足場としてコラーゲンゲルなどの各

\section{3 年 3 月 31 日受付 \\ 2013 年 4 月 27 日掲載決定}

東京工科大学 大学院バイオニクス専攻, †192-0982,

東京都八王子市片倉町 1404-1

Department of Bionics, Tokyo University of Technology, 1404-1, Katakuramachi, Hachioji-shi, Tokyo, 192-0982, Japan
種ゲル 1,2) , ポーラス材料 ${ }^{3-5)}$, 脱細胞組織 6,7 などの生体材料を 使用した研究開発, およびインクジェットプリント技術 8-10) や細胞 シート積層化技術11-14）などの工学技術を使った報告がされてい る.これまでに, 網膜 15), 心臟 16), 骨 17, 18), 皮膚 19) などの組織 におけ 3 次元培養技術が進み, 移植技術への臨床応用も始まっ ている.また，近年では，ゲル加工技術や細胞の積層化技術を 用いた血管構造の再構成やカプセル化技術による 3 次元培養 技術の開発も行われている 20-26).これらの 3 次元培養における 細胞の機能は, 2 次元培養下の細胞機能に比べて, 生体に近い 機能を有することが報告されている. 膵臓細胞においてはインシ ユリン分泌量が 3 次元培養下で増加すること ${ }^{27)}$, 心筋細胞にお いては拍動間隔が 2 次元培養に比べ速く安定したリズムを有する こと, および心臓に存在するタンパク質 ( $\alpha$ アクチニン)の発現量 が増加すること 28-30), 肝臓細胞においては, アルブミンの生成量 が向上することなどの報告がある ${ }^{31)}$.これらの多くの 3 次元培養 
技術は, 細胞を集積化させる技術や細胞の自己組織化を利用し た培養技術である.しかしながら，足場となる 3 次元材料の中に 細胞を埋め込む技術および 3 次元空間に細胞を厳密に配置する 技術の開発は十分に行われていない. 3 次元の足場(材料)の中 に目的の細胞を厳密に空間配置する技術は, (1)より厳密に生体 組織構造を模倣する 3 次元培養技術, (2)幹細胞の効率的な分化 技術, (3)細胞内包型生体適合性材料を用いた移植などへの応 用が期待できる.

我々は組織の中でも, 細胞極性を持ち, 細胞の空間配置およ び突起の伸長方向が機能を発揮する上で重要な役割を果たす 神経組織に着目した. これまでに, 神経科学や工学分野の研究 者らは, 2 次元平面の基板上で, 予め定義された形状の神経回 路を構築する技術を開発してきた. 基板上で, ある特定の形状の 神経回路を構築するのに用いられる一般的な手法は, 細胞接着 基質を基板上にパターニングする化学的な手法(例:マイクロコン タクトプリンティング 32-35), インクジェットプリント ${ }^{36)}$, 表面修飾 37,38), 誘電泳動 39) 等) や, 構造物などを利用した物理的な手法 (例:マイクロ流路デバイス 40,41)，フォトリソグラフィ技術 42 ) 等)であ る. 過去 10 年間で開発されてきた技術により, 細胞間コンタタトや 神経突起の伸長方向をある程度制御した神経ネットワークを構築 することが可能になった.これら開発されてきた技術のほとんどは, 神経細胞を培養するための基板作りにおいて, 高度なクリーン設 備の環境下で複雑な工程を有する微細加工技術を必要としてい る. また, 2 次元平面の培養であり, 生体とは全く異なる環境下で の細胞制御技術となっている. 今後, in vitro で神経組織の生体 環境を模倣するためには, 生体適合性材料を足場とし, 細胞の 空間配置を制御した新しい 3 次元培養技術の開発が求められ る.

そこで, 本研究では, 神経組織の 3 次元構造を模倣する培養 技術として, エキシマレーザを用いた生体適合性材料の 3 次元 加工による細胞埋め込み技術の開発を目的とした. エキシマレー ザは, 高いレーザ光子エネルギーにより, 分子結合を切断するこ とが可能であり, ガラスなどの硬い素材も加工寸ることができるた め, あらゆる生体材料を加工できる可能性がある. また, エキシマ レーザは, レーザ照射による分子結合の切断により, 照射表面に $\mathrm{OH}$ 基や $\mathrm{NH}_{2}$ 基などの官能基置換を可能にする特徵を有してい るため ${ }^{43,44)}$, 加工領域内に細胞外基質をコート寸ることなく培養 できる可能性がある. 本論文では, エキシマレーザを用いたアクリ ル系共重合体シート, コラーゲンファイバーにおける微細加工の 評価, および加工領域内への神経細胞の埋め込みと神経ネット ワークを培養した成果を報告する.

\section{2. 方法}

\section{$2.1 \mathrm{ArF}$ エキシマレーザ}

エキシマレーザ微細加工装置は, 波長 $193 \mathrm{~nm}$ のパルスレーザ である ArF エキシマレーザ加工装置 Micro Master (IPEX-848ArF, GSI Lumonics, Inc.)を用いた. レーザ照射は, 発 振周波数 $50 \sim 200 \mathrm{~Hz}$, パルスエネルギー100〜150 mJ で照射し, 照射パルス数およびスキャン速度は材料の種類に応じて変更し
た、レーザ加工領域の制御は、ピンホールを有したマスクを使用 した(Fig. 1). ピンホール直径 $0.2,0.3,0.4,0.5,0.75,1.0,1.25$, $1.5,2.0 \mathrm{~mm}$ を使用し, 生体材料の加工幅の検討を行った.

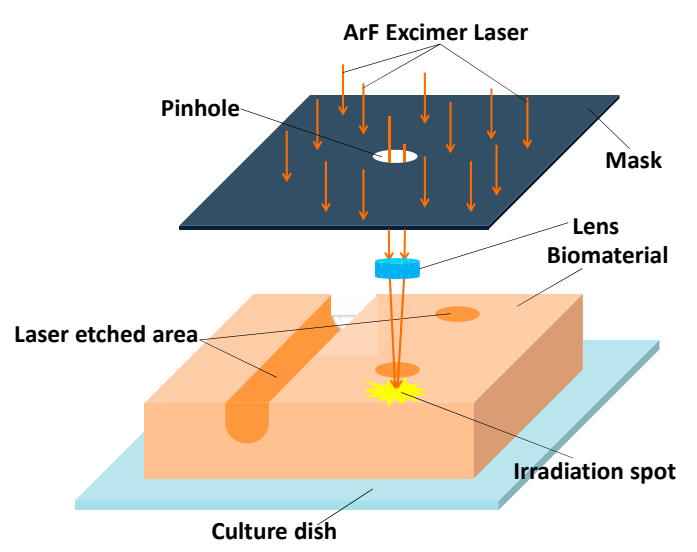

Fig. 1 Micro-fabrication of biomaterials using ArF excimer laser.

\subsection{Block copolymer シートを用いたマイクロ流路の作製}

エキシマレーザによる材料加工の精度および特性を評価する ために, Polydimethylsiloxane（PDMS)などと同じ用途で使用さ れるアクリル共重合体である Block copolymer (BCP) シート (2052, フジデノロ)を用いた. 一般的に PDMS や BCP シートはフ オトリソグラフィ技術によって作製した鋳型を用いてマイクロ流路 などの微細加工が行われる. BCP シートは細胞毒性が無く, 可視 光透過率 $91 \%$, 自家蛍光の無い透明素材である. 厚さ $1 \mathrm{~mm} の$ BCP シートをエキシマレーザ加工装置にセットし, 顕微鏡観察下 でレーザ加工を行った (Fig. 2A-a). 照射条件は, $50 \mathrm{~Hz}, 10$ pulse $/ \mathrm{sec}, 100 \mu \mathrm{m} / \mathrm{sec}$ で行い, ピンホール直径 0.2〜2.0 mm のマ スクを使用した. 加工した $\mathrm{BCP}$ シートを上下反転し, $35 \mathrm{~mm}$ non-treated dish（1000-035, Iwaki）に接着させ, マイクロ流路を 構築した. マイクロ流路が構築されているかを調べるために, 蛍 光色素である Acid Blue 1 (Tokyo chemical industry Co., LTD.), Tetramethylrhodamine (TMR, Cytodiagnostics, Inc.) を流した. TMR によるマイクロ流路の確認は, Electron Multiplying CCD カ メラ(iXon Ultra 897, Andor, USA)を用いて蛍光観察した。

\section{3 コラーゲンファイバーのエキシマレーザ加エ}

生体材料としてコラーゲンファイバーを用いた. 直径 $12 \mathrm{~mm}$ の ガラスベースデイッシュ(11-0602, Iwaki)に Rat tail collagen type I 溶液 (Life Technologies) $2 \mathrm{mg} / \mathrm{ml}$ を $200 \mu \mathrm{l}$ 滴下L, $37^{\circ} \mathrm{C}, 5 \%$ $\mathrm{CO}_{2}$ インキュベータ内に 5 分間入れ, ゲルを架橋した. その後, 真空乾燥機で 24 時間乾燥させ, コラーゲンファイバーを作製し た. 次に加工領域内のみに培養を行うために, コラーゲンファイ バー上に細胞非接着分子である分子量 6,000 の $100 \mu \mathrm{M}$ polyethylene glycol (PEG, Wako) 溶液を $50 \mu \mathrm{l}$ 滴下L, 真空乾 燥機で乾燥した. エキシマレーザの照射条件は $200 \mathrm{~Hz}, 50$ pulse $/ \mathrm{sec}, 50 \mu \mathrm{m} / \mathrm{sec}$ で行い, ピンホール直径 0.2〜1.0 mm のマ スクを使用した。

\section{4 海馬初代培養細胞の調製と培養法}

レーザ加工領域に埋め込む細胞として, Rat 海馬初代培養細 
胞を用いた. 妊娠 18 日目のWister Rat胎児をDissection Medium (Hank's balanced salt solution (HBSS), 1mM pyruvic acid, 10 mM HEPES, pH7.2) 中に取り出し, 実体顕微鏡下で海馬を採取 した. その後, Trypsin $(0.5 \mathrm{mg} / \mathrm{ml})$ と DNase $(0.1 \mathrm{mg} / \mathrm{ml})$ を含む HBSS にて $37^{\circ} \mathrm{C} て ゙ ~ 15$ 分間酵素処理を行い, $4^{\circ} \mathrm{C}, 1000 \mathrm{rpm}$ で 5 分間遠心分離した. 10\% Fatal Bovine Serum(FBS, Invitrogen Corp, CA, USA) を含む HBSS を加えて酵素処理を止め, Dissection medium にて $4^{\circ} \mathrm{C}, 1000 \mathrm{rpm}, 5$ 分間の遠心を 3 回繰り 返した. 最後に, $40 \mu \mathrm{m}$ セルストレーナーに通し, $1 \times 10^{6} \mathrm{cell} / \mathrm{ml}$ の 濃度で精製した初代培養細胞を得た. 細胞培養に使用した培地 は Neurobasal medium (Invitrogen)に $2 \% \mathrm{v} / \mathrm{v}$ B27sapplement (Invitrogen ), $0.074 \mathrm{mg} / \mathrm{ml} \mathrm{L-glutamine} \mathrm{(Sigma-aldrich),} 50$ $\mu \mathrm{g} / \mathrm{ml}$ Gentamycin Reagent Solution (Invitrogen ) 100U/ml Penicillin/Streptomycin（Invitrogen）を加えたものを基本とした. 基板上に $1 \times 10^{6} \mathrm{cell} / \mathrm{ml}$ の細胞懸濁液を $50 \mu \mathrm{l}$ 播種し, $37^{\circ} \mathrm{C}$,

$5 \% \quad \mathrm{CO}_{2}$ 環境下のインキュベータで培養した.

\section{5 免疫化学染色}

コラーゲンファイバーの加工および培養された神経細胞を確 認するために, 免疫化学染色を行った. $4{ }^{\circ} \mathrm{C}$ の $4 \%$ パラホルムア ルデヒド溶液にて, サンプルを水上で 20 分間固定後, $-20^{\circ} \mathrm{C}$ メ ノールで, 10 分間固定した. その後, 非特異吸着を無くすために, Preblock buffer $(0.05 \%$ Triton-X, 5\% fatal bovine serum を

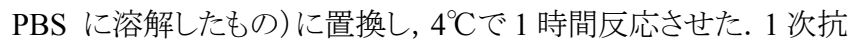
体として, コラーゲン繊維を同定するための anti-Collagen type I 抗体 (anti-rabbit, chemicon)，神経細胞を同定するための anti- $\beta$-tubulin III (anti-mouse, chemicon)を Preblock buffer に

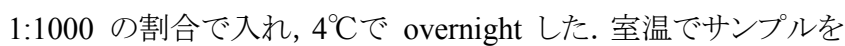
15 分間に 3 回 Preblock buffer で洗い, 2 次抗体として Alexa Fluor 546 (anti-rabbit IgG, Molecular Probes, Inc., OR)と Alexa Fluor 488 (anti-mouse IgG, Molecular Probes, Inc., OR), 核を同 定するための Hoechst33258 を 1:1000 の割合で Preblock buffer に溶かし, 1 時間反応させた. 1 時間後, Preblock buffer で洗い, 15 分おきに PBS で 2 回洗ったサンプルを蛍光顕微鏡 (BZ-9000, Keyence, Inc.)を用いて観察した.

\section{6 電子顕微鏡観察}

レーザ加工によるコラーゲン繊維の除去および神経細胞や神 経突起の埋め込みを確認するために, 走査型電子顕微鏡 (JSM-7700F，JEOL)を用いて観察した. 走査型電子顕微鏡で観 察するための細胞固定を以下に示す. 室温で, サンプルを 5 分 毎にPBS で 2 回洗浄し, $2.5 \%$ グルタルアルデヒド $0.1 \mathrm{M}$ リン酸バ ッファー $(\mathrm{pH} 7.2 \sim 7.4)$ で 20 分間固定した. その後, 8\%スクロース $0.1 \mathrm{M}$ リン酸バッファーで $15 \sim 20$ 分毎に 4 回洗浄し, $1 \%$ 四酸化才 シミウム固定液で 20 分間固定した。次に, 50\%, 70\%, 80\%, 90\%, 95\%アルコールの順で 15～20 分間隔で溶液交換を行い, $100 \%$ 無水アルコールを用いて 15 分間隔で 4 回の溶液交換, 酢 酸イソアミルで 2 回の溶液交換を行った. その後, サンプルを真 空乾燥機にて 24 時間乾燥させた.

細胞固定したサンプルは, カーボンテープで試料台に固定し, Pt コーター (JFC-1600, JEOL) にて白金を蒸着させた. 蒸着条件
は真空度: $3.00 \times 10^{-5} \mathrm{pa}$, 電流值: $10 \mathrm{~mA}$, 蒸着時間: 35 秒 $\times 5$ 回 とした. 電子顕微鏡観察は加速電圧 $5 \mathrm{kV}$ の条件で行った.

\section{3. 結果と考察}

\section{1 エキシマレーザ加エによるマイクロ流路の構築}

エキシマレーザによる微細加工の精度および特性を評価する ために, アクリル系重合体である BCPシートを用いた. BCPシート は, 透明素材であり, 細胞パターニングやマイクロ流路を用いた 細胞分離などに使用されている PDMS と同じ用途での使用が可 能であると共に, 基板への接着性が高い特性を有している. 一般 的にPDMS や BCPシートはフォトリソグラフィー技術によって作製 した鋳型を用いてマイクロ流路などの微細加工が行われる.ここ では, 複雑な工程を有する鋳型の作製なしで, エキシマレーザ加 工によってマイクロ流路が簡便に構築できるかを評価した.

A

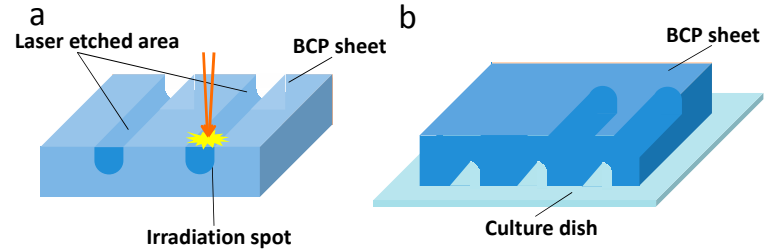

B a
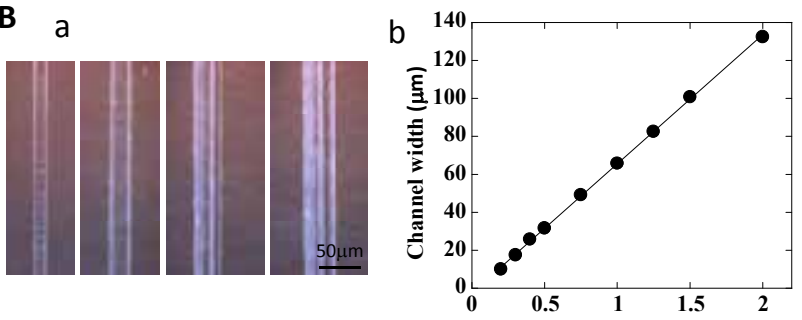

C

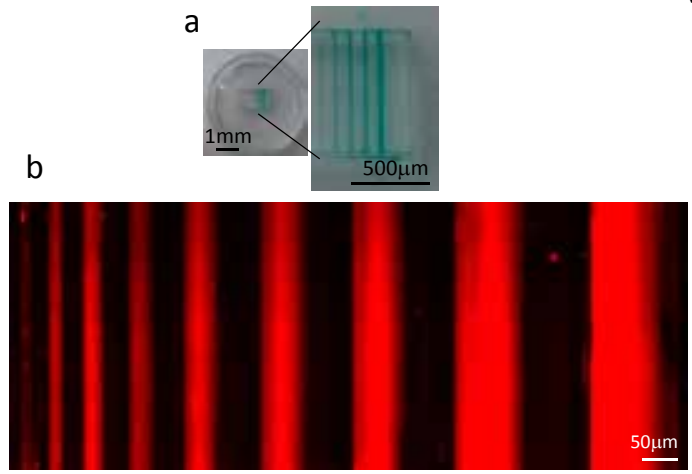

Pinhole diameter $(\mathrm{mm})$

Fig. 2 Fabrication of microchannel in $\mathrm{BCP}$ sheet using excimer laser. A: Schematic drawing of microchannel processing. B: Phase contrast images of microchannels fabricated by different pinhole size (a). Relationship between the pinhole diameter and processed channel width (b). C: Overview of microchannel stamp on the 35 $\mathrm{mm}$ dish (a). The photo shows a state in which flow into the microchannels Acid blue1. Lower picture shows the fluorescent image flowed into the microchannels the TMR (b).

ピンホール直径 $0.2,0.3,0.4,0.5,0.75,1.0,1.25,1.5,2.0$ $\mathrm{mm}$ のマスクを使用し, $10 \mathrm{pulse} / \mathrm{sec}, 100 \mu \mathrm{m} / \mathrm{sec}$ の条件で直線状 
に加工した. Fig. 2B-a は, 左からピンホール直径 0.2, 0.3, 0.5, $0.75 \mathrm{~mm}$ で加工した位相差像を示している. 流路幅はそれぞれ $10.9,17.5,31.7,49.2 \mu \mathrm{m}$ で加工されていた. 位相差像に見られ る縞模様は, $10 \mathrm{pulse} / \mathrm{sec}, 100 \mu \mathrm{m} / \mathrm{sec}$ の条件で照射したパルス による加工の跡である. Fig. 2B-b にエキシマレーザのピンホール 直径と流路幅の関係を示す. 検量線の r 值が 0.999 となったこと からピンホール直径と流路幅の間に強い相関があることが確認さ れた. マスクによる照射幅の制御においては, 最小加工幅が 10 $\mu \mathrm{m}$, 最大加工幅が $133 \mu \mathrm{m}$ であった. 深さ方向への加工はマス クサイズに依存した顕著な差はなく, 27.4 $23.0 \mu \mathrm{m}$ (平均土標準 偏差)であった. 同一箇所にパルスを照射し続けた場合には, 厚 さ $1 \mathrm{~mm}$ の BCP シートを貫通したマイクロチャンネルが作製され た.

次に, 加工した BCP シートをシャーレに接着させ, マイクロ流路 が構築されているかを, 蛍光色素を流して確認した. Fig. 2C-a に Acid Blue 1 を流した写真を示す. マイクロ流路内に色素が流れ ていることを確認した. Fig. 2C-b は, 流路幅 $10 \mu \mathrm{m}$ から $133 \mu \mathrm{m}$ までのマイクロ流路に蛍光色素 TMR を流し, 蛍光観察した写真 を示している. 流路幅 $10 \mu \mathrm{m}$ においても, マイクロ流路が形成さ れ, マスクを変更することによって, 流路幅を制御したマイクロ流 路を構築できることがわかった.

これらの結果より, エキシマレーザにより $\mathrm{BCP}$ シートの微細加 工が可能であること, および鋳型を用意することなく, $10 \mu \mathrm{m}$ の精 度で自在なマイクロ流路を簡便に構築できることがわかった. 本 技術は，マイクロ流路を用いた研究や技術開発の分野において も大いに応用が期待できる.

\section{2 エキシマレーザによるコラーゲンファイバーの加エ}

次に, 生体材料であるコラーゲンファイバーのエキシマレーザ による加工の評価を行った. 厚さ約 $10 \mu \mathrm{m}$ のコラーゲンファイバ 一をピンホール直径 $0.2,0.3,0.4,0.5,0.75 \mathrm{~mm}$ のマスクを使用 し, $50 \mathrm{pulse} / \mathrm{sec}, 50 \mu \mathrm{m} / \mathrm{sec}$ の条件で直線上に加工した. Fig. 3B-a は, 左からピンホール直径 0.75, 0.5, 0.4, 0.3, $0.2 \mathrm{~mm}$ で加 工した位相差像を示している. Fig. 3B-b は, 加工後にコラーゲン タイプ I 抗体で免疫染色した画像(赤)である. 流路幅は, それぞ れ 101.7, 65.4, 43.6, 23.5, $11.6 \mu \mathrm{m}$ で加工されており, レーザ照 射領域のコラーゲンファイバーが全てエッチングされていることが 確認された. Fig. 3B-c は, 流路幅 $11.6 \mu \mathrm{m}$ で加工した領域の電 子顕微鏡写真である. 最小ピンホールサイズにおいても, 完全に コラーゲンファイバーがエッチングされている様子が観察された.

Fig. 3B-d にエキシマレーザのピンホール直径と流路幅の関係を 示す． 検量線の $\mathrm{r}$ 值が 0.995 となったことからピンホール直径と 流路幅の間に相関があることが確認された. また, スキャン速度を 遅くし，照射パルス数を上げることで，均一な加工ができることも 確かめられた.これらの結果より, エキシマレーザにより, コラーゲ ンファイバーを簡便に微細加工できることがわかった.

\section{3 レーザ加工領域への神経細胞の埋め込み}

次に，レーザ加工領域への神経細胞の埋め込みを評価した. 加工領域のみに細胞を埋め込むために, 細胞非接着基質である PEG をコラーゲンファイバー上にコーティングした(Fig. 3A). コラ
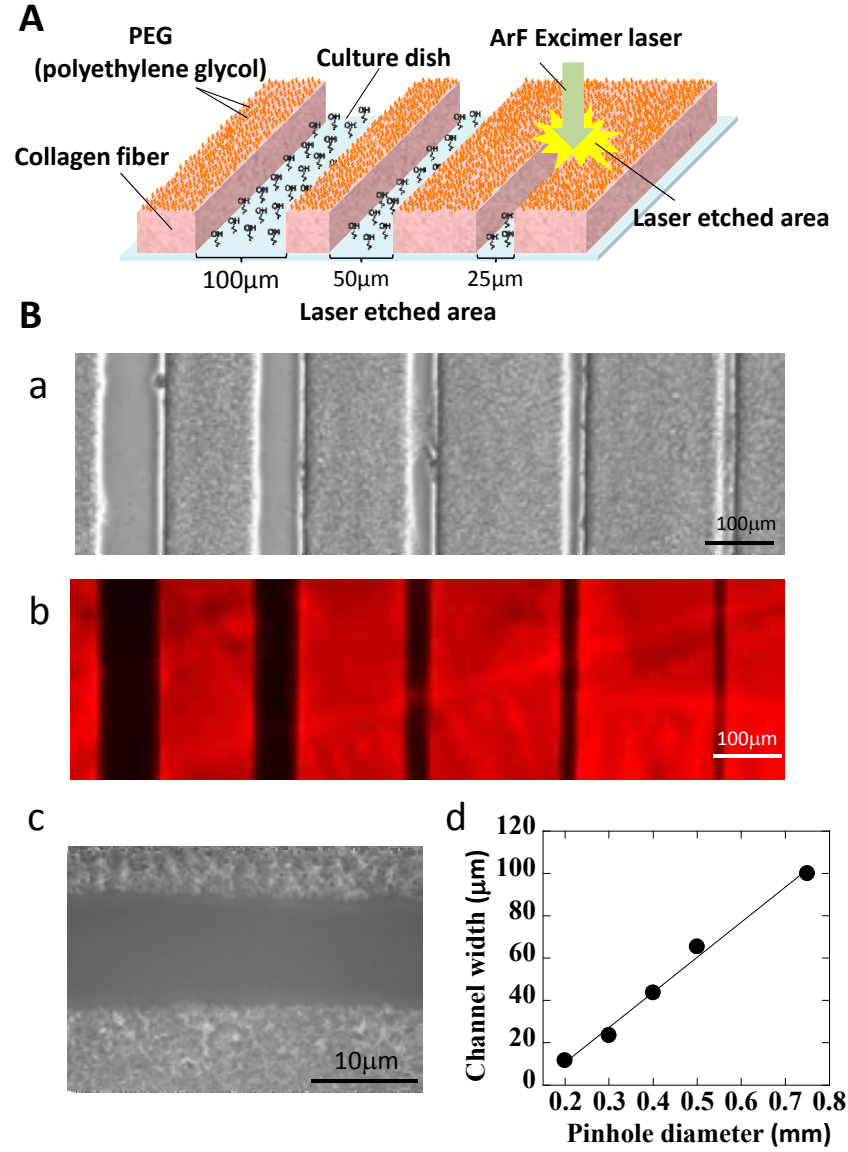

Fig. 3 Micro-fabrication of collagen fibers using excimer laser. A: Schematic drawing of micro-fabrication. B: Phase contrast images of etched collagen fibers by different pinhole size (a). Fluorescent image of immunostaining by anti-collagen type I (b). Scanning electron microscopic (SEM) image of etched collagen fibers using pinhole size $20 \mathrm{~mm}$ (c). Relationship between the pinhole diameter and processed channel width (d).

ーゲンファイバーをレーザ加工した基板上に Rat 海馬初代培養 細胞を播種し, 培養の様子を観察した. Fig. 4A-a は培養 4 日目 に固定し, 免疫化学染色を行った結果である. 神経細胞のマー カーである $\beta$-tubulin III (緑), コラーゲン繊維のマーカーである Collagen Type I (赤), 核のマーカーである Hoechts 33258 (青) で染色し, 各画像を重㸚あせた写真である. 画像から見てわか るように, 加工領域内のみに神経細胞の接着および神経突起の 伸長が観察された. 上段から, ピンホール直径 $0.75,0.5,0.4,0.3$, $0.2 \mathrm{~mm}$ で加工した領域を示しており, 最下段は, 最小のピンホー ル直径 $0.2 \mathrm{~mm}$ を使用し, マスク上部に設置されているバリアブル アパチャーにてレーザ照射領域を絞り込み, 流路幅 $5 \mu \mathrm{m}$ で加工 した領域である. Fig. 4B および $4 \mathrm{C}$ は, 流路幅 $43 \mu \mathrm{m}$ および $5 \mu \mathrm{m}$ に培養された神経細胞の拡大写真である. 神経細胞が加工領域 からはみ出ることなく培養されている様子および神経突起が伸長 している様子を示している. 流路幅 $5 \mu \mathrm{m}$ における培養では, 神 経突起が一方向に伸長している様子が観察された. Fig. 4A-b は, 
A

a

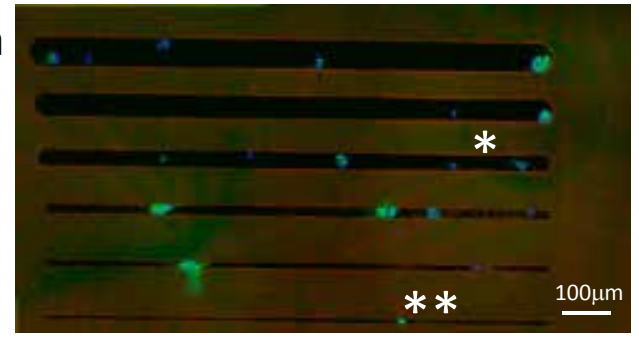

b

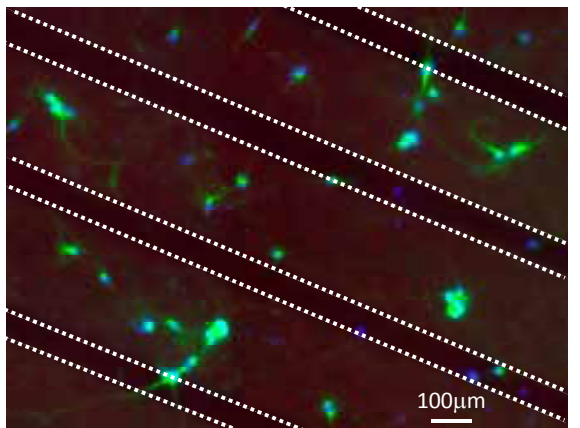

B

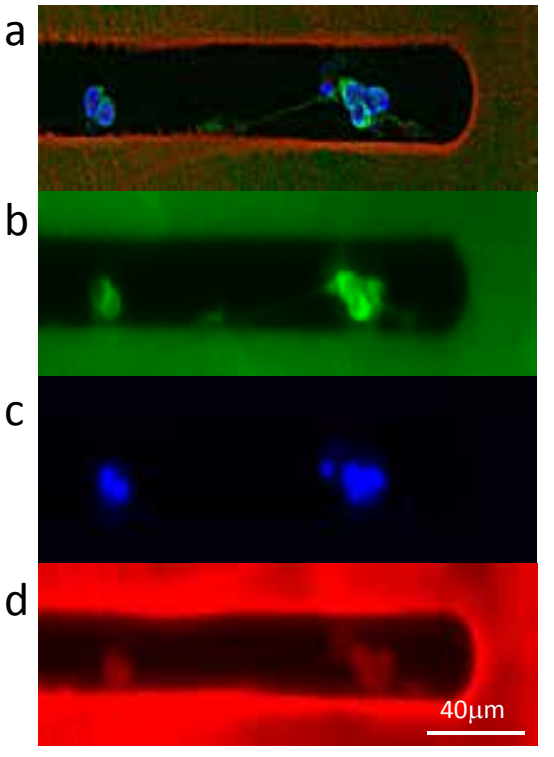

C

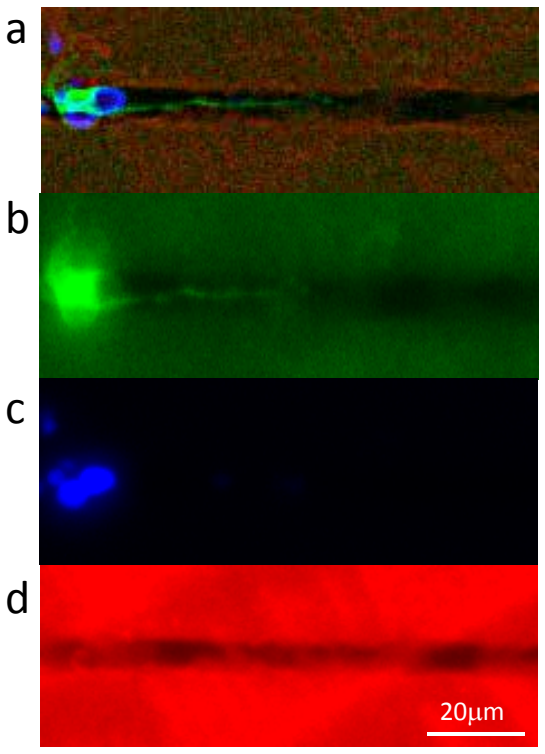

Fig. 4 Cultured neuronal networks in collagen fiber etched area. A: Fluorescent image of cultured rat hippocampal neurons in collagen fiber etched are of different channel width (a). Red staining indicates collagen type 1 fibers. Neurons were stained for $\beta$-tubulin III(Green). Blue is the Hoechst 33258 nuclear stain. Lower micrograph shows fluorescent image of cultured neurons in non-treated PEG dish. White dot line indicates collagen etched area. B: Magnified view of cultured neurons in $43 \mu \mathrm{m}$ channel width. C: Magnified view of cultured neurons in 5 $\mu \mathrm{m}$ channel width.

\section{A}

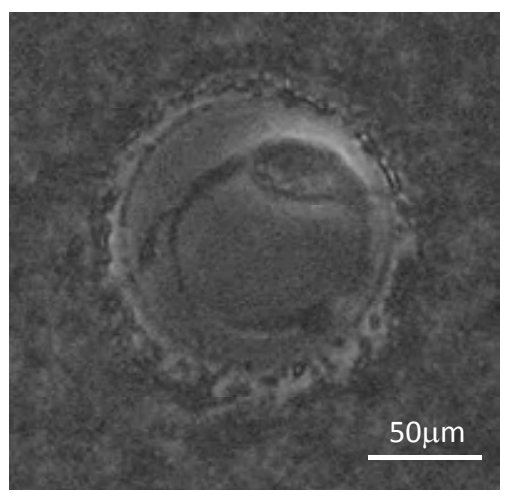

B

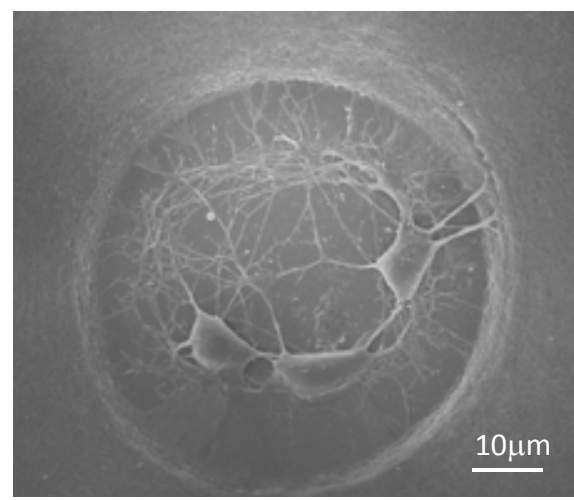

C

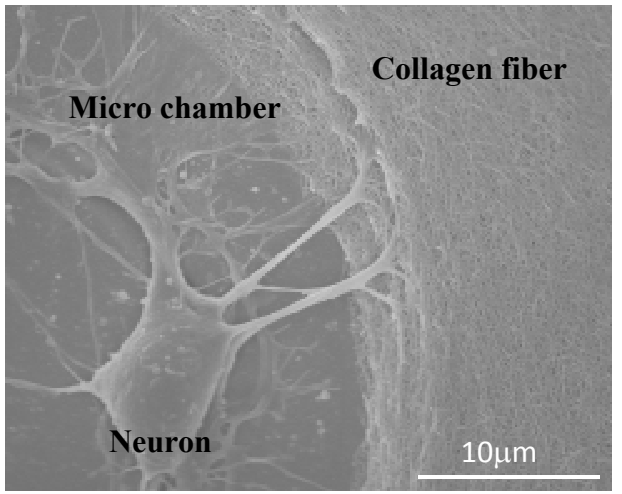

Fig. 5 Embedded neurons in microchamber. A: Phase contrast image of embedded single neuron in microchamber of $102 \mu \mathrm{m}$ diameter. B: SEM image of embedded three neurons in microchamber of $65 \mu \mathrm{m}$ diameter. C: Magnified view of SEM image B.

PEG コーティングなしで, 加工した基板に培養した様子を示して いる. 加工領域内外共に, 神経細胞が培養されている様子が観 察された.このことから, 加工領域内のみの細胞接着はコラーゲ ンファイバー上にコーティングした PEG の効果であることが示唆さ れた. 従来PEGを基板に修飾させる際には, チオール結合により 形成させるが, 本実験では真空乾燥のみでコーティングした. PEG を添加させた場合には, 細胞が生着しなかったことから, コラ 一ゲンファイバーへ PEG が吸着していたと考えられる. 本実験に おけるレーザ加工領域はガラス面が露出しており, 細胞接着基質 のコーティングは行なっていない. 通常, ハンコーティングのガラ
ス表面には Rat 海馬初代培養細胞は接着しないが, 本実験にお いて接着が見られた. エキシマレーザのガラス面への照射は, $\mathrm{OH}$ 基を露出させ, 表面を親水化させる報告がある ${ }^{44)}$. ガラス基 板表面の改質により, 細胞の接着および培養が可能になったと 考えている. 細胞外基質のコートなしでエキシマレーザの加工領 域に培養できることはエキシマレーザ加工技術の神経細胞培養 における長所である.

次に, マイクロチャンバーへの神経細胞の埋め込みを評価した. Fig. 5A は, ピンホール直径 $0.75 \mathrm{~mm}$ で加工した直径 $102 \mu \mathrm{m}$ の チャンバーに1細胞培養されている位相差像である. Fig. 5B は, 
ピンホール直径 $0.5 \mathrm{~mm}$ で加工した直径 $65 \mu \mathrm{m}$ のチャンバーに 3 細胞が埋め込まれ培養されている様子の電子顕微鏡写真である. チャンバー内にのみ培養され, コラーゲンファイバー表面に突起 がはみ出していない様子が観察された. Fig. 5C は 5B の拡大写 真であり, コラーゲン繊維が完全にエッチングされている様子お よび神経突起が底面に伸長している様子を示している.

本実験は, 生体材料としてコラーゲンファイバーをエキシマレ ーザ加工することにより細胞を埋め込んだ. 加工領域内に神経ネ ットワークの埋め込みに成功したことから, エキシマレーザ加工に より生体材料深部への細胞導入の可能性が示唆された.しかし ながら, エキシマレーザ加工により, 細胞の接着性, 増殖性, 移 動性などの厳密な細胞挙動を制御するためには, より微細な加 工精度が必要となる. サブミクロンオーダーの加工精度について は今後の課題である.

\section{4 神経突起の $Z$ 軸方向への誘導}

神経ネットワークの情報伝達を担う上で重要な役割を持つ神経 突起の方向を Z 軸に誘導することを試みた. ピンホール直径 0.2 $\mathrm{mm}$ のマスクを用いて流路幅 $10 \mu \mathrm{m}$ のマイクロチャンネルを作製 し, 神経細胞を並べ, 更に, マイクロチャンネル内に $50 \mu \mathrm{m}$ 間隔で 直径 $5 \mu \mathrm{m}$ の Z 軸方向への加工を行うことで, 神経突起を Z 軸方 向に誘導することを試みた(Fig. 6A). Fig. 6B はコラーゲンファイ バーを加工した幅 $10 \mu \mathrm{m}$ のマイクロチャンネルに神経細胞を並べ た培養 4 日目の写真を示している. 神経細胞がマイクロチャン ネル内のみに接着している様子, および神経突起が直線状に伸 長し, 細胞間で結合している様子が観察された. マイクロ流路内 に $50 \mu \mathrm{m}$ 間隔で白く見える箇所が Z 軸方向に加工したホールで ある. Z 軸に加工したホールに神経突起が落ち込んでいるかを確 認するために, 電子顕微鏡にて観察した. Fig. 6C は, Z 軸方向に 加工したホールに神経突起が落ち込んでいる様子を示している.

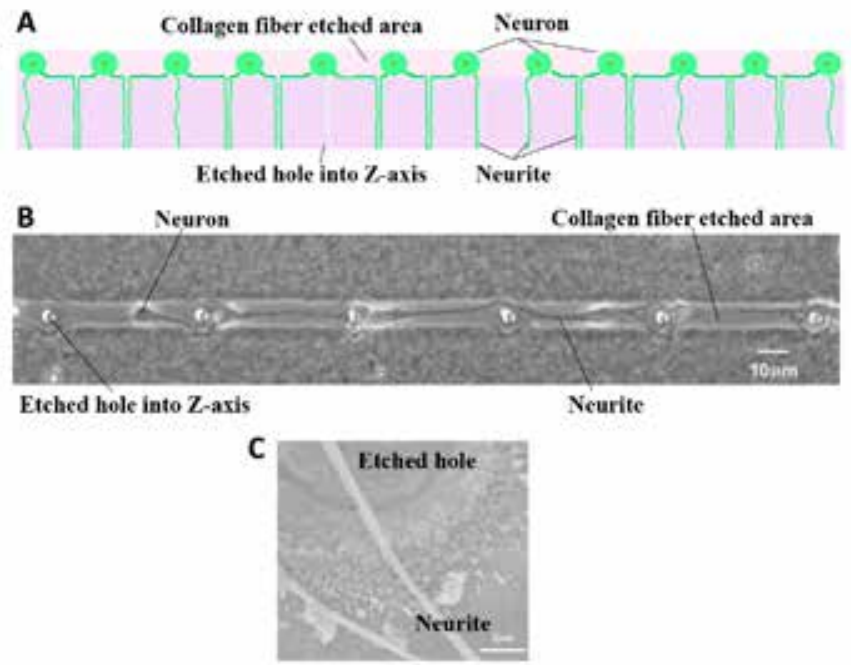

Fig. 6 Neurite elongation into the etched hole in Z-axis. A: Schematic drawing of neurite guidance into the etched hole. B: Phase contrast image of linearly cultured neuronal network in microchannel of $10 \mu \mathrm{m}$ width. C: SEM image of neurite elongation into etched hole in Z-axis.
これらの結果より, 神経突起のみを Z 軸方向に誘導できる可能 性が示唆された. 本実験では, ガラスを Z 軸方向に加工したが, 厚い生体材料を用いれば, 生体材料中に異なる幅のマイクロチ ヤンネルを Z 軸方向に加工することが可能であり, 細胞のみなら ず, 神経突起の空間的制御ができる. 今後, 生体材料深部への 加工を行い, 神経突起の伸長方向を 3 次元空間内で制御した新 しい 3 次元培養技術へと発展させたい.

\section{4. おわりに}

本研究では, 生体適合性材料の 3 次元空閒に神経細胞を意 図した位置に配置する 3 次元培養技術の開発を目的とし, エキシ マレーザを用いた微細加工による神経細胞の埋め込みを試みた. エキシマレーザの微細加工の精度および特性を最初に評価する にあたり，BCPシートとコラーゲンファイバーを用いた. BCPシート の加工において, $10 \mu \mathrm{m}$ の精度で微細加工することができた。エ キシマレーザによる BCP シートの加工技術は, マイクロ流路の作 製において, 鋳型を必要としない簡便な作製技術であることがわ かった. 生体材料としてコラーゲンファイバーをエキシマレーザ加 工した結果, $5 \mu \mathrm{m}$ の精度で微細加工することができた.このこと から，1細胞レベルで細胞を埋め込むことのできる精度で加工で きることがわかった。 また，材料表面に細胞非接着分子である PEG を修飾することで, レーザ加工領域内のみに神経細胞を埋 め込むことに成功した. 照射領域の表面改質を行うエキシマレー ザの特徵により, 細胞接着基質をコートすることなく, 加工領域内 に神経細胞を培養できることがわかった. 更に, エキシマレーザ 加工領域に埋め込んだ神経細胞の神経突起を $\mathrm{Z}$ 軸方向に加工 した穴に誘導することに成功した. これらの結果は, エキシマレー ザにより生体材料の微細加工が可能であること, および生体材料 中への神経細胞の埋め込みや細胞の空間配置を制御できる可 能性を示唆している. 生体適合性材料を用いた 3 次元培養技術 へと発展させるためには, 生体適合性材料の選定, 柔らかい生 体材料のレーザ加工評価, 3 次元空間への細胞の浸潤などを評 価して行く必要があり, 今後の課題である.

\section{謝辞}

本研究は, JSPS 科研費 24700485 の助成を受けて行われた.

\section{参考文献}

1) J.Erickson, A.Tooker, Y.C.Tai, J.Pine, Caged neuron MEA: a system for long-term investigation of cultured neural network connectivity. Journal of neuroscience methods 2008; 175(1): 1-16.

2) S. Raghavan, C.M. Nelson, J.D. Baranski, E.Lim, C.S.Chen, Geometrically controlled endothelial tubulogenesis in micropatterned gels. Tissue engineering Part A 2010; 16(7): 2255-2263.

3) A.K. Ekaputra, G.D.Prestwich, S.M.Cool, D.W.Hutmacher, The three-dimensional vascularization of growth factorreleasing hybrid scaffold of poly (epsilon-caprolactone)/ 
collagen fibers and hyaluronic acid hydrogel. Biomaterials 2011; 32(32): 8108-8117.

4) M.Fujita, Y.Kinoshita, E.Sato, H.Maeda, S.Ozono, H.Negishi, et al. Proliferation and differentiation of rat bone marrow stromal cells on poly(glycolic acid)-collagen sponge. Tissue engineering 2005; 11(9-10): 1346-1355.

5) Y.Hiraoka, Y.Kimura, H.Ueda, Y.Tabata, Fabrication and biocompatibility of collagen sponge reinforced with poly (glycolic acid) fiber. Tissue engineering 2003; 9(6): 1101-1112.

6) K.H.Nakayama, C.A.Batchelder, C.I.Lee, A.F.Tarantal, Decellularized rhesus monkey kidney as a three-dimensional scaffold for renal tissue engineering. Tissue engineering Part A 2010; 16(7): 2207-2216.

7) P.Vavken, S.Joshi, M.M.Murray, TRITON-X is most effective among three decellularization agents for ACL tissue engineering. Journal of orthopaedic research 2009; 27(12): 1612-1618.

8) X.Cui, T.Boland, Human microvasculature fabrication using thermal inkjet printing technology. Biomaterials 2009; 30(31): 6221-6227.

9) M.Matsusaki, K.Sakaue, K.Kadowaki, M.Akashi, Three-Dimensional Human Tissue Chips Fabricated by Rapid and Automatic Inkjet Cell Printing. Advanced healthcare materials 2012; 2(4): 534-539.

10) S.Moon, S.K.Hasan, Y.S.Song, F.Xu, H.O.Keles, F.Manzur, et al. Layer by layer three-dimensional tissue epitaxy by cell-laden hydrogel droplets. Tissue engineering Part C Methods 2010; 16(1): 157-166.

11) Y.Haraguchi, T.Shimizu, T.Sasagawa, H.Sekine, K.Sakaguchi, T.Kikuchi, et al. Fabrication of functional three-dimensional tissues by stacking cell sheets in vitro. Nature protocols 2012; 7(5): 850-858.

12) M.Kino-oka, T.X.Ngo, E.Nagamori, Y.Takezawa, Y.Miyake, Y.Sawa, et al. Evaluation of vertical cell fluidity in a multilayered sheet of skeletal myoblasts. Journal of bioscience and bioengineering 2012; 113(1): 128-131.

13) J.Yang, M.Yamato, C.Kohno, A.Nishimoto, H.Sekine, F.Fukai, et al. Cell sheet engineering: recreating tissues without biodegradable scaffolds. Biomaterials 2005; 26(33): 6415-6422.

14) T.Shimizu, M.Yamato, T.Akutsu, T.Shibata, Y.Isoi, A.Kikuchi, et al. Electrically communicating threedimensional cardiac tissue mimic fabricated by layered cultured cardiomyocyte sheets. Journal of biomedical materials research 2002; 60(1): 110-117.

15) J.Yang, M.Yamato, K.Nishida, T.Ohki, M.Kanzaki, H.Sekine, et al. Cell delivery in regenerative medicine: the cell sheet engineering approach. Journal of controlled release : official journal of the Controlled Release Society 2006; 116(2): 193-203.

16) A.Furuta, S.Miyoshi, Y.Itabashi, T.Shimizu, S.Kira, K.Hayakawa, et al. Pulsatile cardiac tissue grafts using a novel three-dimensional cell sheet manipulation technique functionally integrates with the host heart, in vivo. Circulation research 2006; 98(5): 705-712.

17) C.Erggelet, M.Sittinger, A.Lahm, The arthroscopic implantation of autologous chondrocytes for the treatment of full-thickness cartilage defects of the knee joint. Arthroscopy: the journal of arthroscopic \& related surgery: official publication of the Arthroscopy Association of North America and the International Arthroscopy Association 2003; 19(1): 108-110.

18) A.Gobbi, E.Kon, M.Berruto, R.Francisco, G.Filardo, M.Marcacci, Patellofemoral full-thickness chondral defects treated with Hyalograft-C: a clinical, arthroscopic, and histologic review. The American journal of sports medicine 2006; 34(11): 1763-1773.

19) S.Ikuta, N.Sekino, T.Hara, Y.Saito, K.Chida, Mouse epidermal keratinocytes in three-dimensional organotypic coculture with dermal fibroblasts form a stratified sheet resembling skin. Bioscience, biotechnology, and biochemistry 2006; 70(11): 2669-2675.

20) S.Sugaya, S.Kakegawa, S.Fukushima, M.Yamada, M.Seki, Micropatterning of hydrogels on locally hydrophilized regions on PDMS by stepwise solution dipping and in situ gelation. Langmuir : the ACS journal of surfaces and colloids 2012; 28(39): 14073-14080.

21) N.Sadr, M.Zhu, T.Osaki, T.Kakegawa, Y.Yang, M.Moretti, et al. SAM-based cell transfer to photopatterned hydrogels for microengineering vascular-like structures. Biomaterials 2011; 32(30): 7479-7490.

22) K.Sakaguchi, T.Shimizu, S.Horaguchi, H.Sekine, M.Yamato, M.Umezu, et al. In vitro engineering of vascularized tissue surrogates. Scinentific Reports 2013; 19(3): 1316.

23) T.T.Dang, Q.Xu, K.M.Bratlie, E.S.O'Sullivan, X.Y.Chen, R.Langer, et al. Microfabrication of homogenous, asymmetric cell-laden hydrogel capsules. Biomaterials 2009; 30(36): 6896-6902.

24) M.Kato-Negishi, Y.Tsuda, H.Onoe, S.Takeuchi, A neurospheroid network-stamping method for neural transplantation to the brain. Biomaterials 2010; 31(34): 8939-8945.

25) Y.T.Matsunaga, Y.Morimoto, S.Takeuchi, Molding cell beads for rapid construction of macroscopic 3D tissue architecture. Advanced materials 2011; 23(12): 90-94.

26) Y.Morimoto, R.Tanaka, S.Takeuchi, Construction of 3D, Layered Skin, Microsized Tissues by Using Cell Beads for 
Cellular Function Analysis. Advanced healthcare materials 2013; 2(2): 261-205.

27) Y.Tsuda, Y.Morimoto, S.Takeuchi, Monodisperse cell-encapsulating peptide microgel beads for 3D cell culture. Langmuir 2010; 26(4): 2645-2649.

28) M.Zhao, C.Song, W.Zhang, Y.Hou, R.Huang, Y.Song, et al. The three-dimensional nanofiber scaffold culture condition improves viability and function of islets. Journal of biomedical materials research Part A 2010; 94(3): 667-672.

29) X.M.Liu, H.Liu, F.Y.Xiong, Z.L.Chen, Collagen membrane as scaffold for the three-dimensional cultivation of cardiac cells in vitro. Chinese journal of biotechnology 2003; 19(4): 484-488.

30) C.Pontes Soares, V.Midlej, M.E.de Oliveira, M.Benchimol, M.L.Costa, C.Mermelstein, 2D and 3D-organized cardiac cells shows differences in cellular morphology, adhesion junctions, presence of myofibrils and protein expression. PloS one 2012; 7(5): e 38147.

31) F.Evenou, M.Hamon, T.Fujii, S.Takeuchi, Y.Sakai, Gas-permeable membranes and co-culture with fibroblasts enable high-density hepatocyte culture as multilayered liver tissues. Biotechnology progress 2011; 27(4): 1146-1153.

32) J.C.Chang, G.J.Brewer, B.C.Wheeler, A modified microstamping technique enhances polylysine transfer and neuronal cell patterning. Biomaterials 2003; 24(17): 2863-2870

33) A.K.Vogt, G.J.Brewer, T.Decker, S.Bocker-Meffert, V.Jacobsen, M.Kreiter, et al. Independence of synaptic specificity from neuritic guidance. Neuroscience 2005; 134(3): 783-790

34) A.C.von Philipsborn, S.Lang, A.Bernard, J.Loeschinger, C.David, D.Lehnert, et al. Microcontact printing of axon guidance molecules for generation of graded patterns. Nature protocols 2006; 1(6): 1322-1328.

35) Z.Zhang, R.Yoo, M.Wells, T.P.Beebe, R.Jr., Biran, P.Tresco, Neurite outgrowth on well-characterized surfaces: preparation and characterization of chemically and spatially controlled fibronectin and RGD substrates with good bioactivity. Biomaterials 2005; 26(1): 47-61.

36) N.E.Sanjana, S.B.Fuller, A fast flexible ink-jet printing method for patterning dissociated neurons in culture. Journal of neuroscience methods. 2004; $136(2)$ : 151-163.

37) S.J.Kim, J.K.Lee, J.W.Kim, J.W.Jung, K.Seo, S.B.Park, et al. Surface modification of polydimethylsiloxane (PDMS) induced proliferation and neural-like cells differentiation of umbilical cord blood-derived mesenchymal stem cells. Journal of materials science Materials in medicine 2008; 19(8): 2953-2962.

38) E.M.Regan, J.B.Uney, A.D.Dick, Y.Zhang, J.Nunez-Yanez,
J.P.McGeehan, et al. Differential patterning of neuronal, glial and neural progenitor cells on phosphorus-doped and UV irradiated diamond-like carbon. Biomaterials 2010; 31(2): 207-215.

39) Z.Yin, D.Noren, C.J.Wang, R.Hang, A.Levchenko, Analysis of pairwise cell interactions using an integrated dielectrophoretic-microfluidic system. Molecular systems biology 2008; 4: 232.

40) L.J.Millet, M.E.Stewart, R.G.Nuzzo, M.U.Gillette, Guiding neuron development with planar surface gradients of substrate cues deposited using microfluidic devices. Lab on a chip 2010; 10(12):1525-15 35 .

41) A.M.Taylor, M.Blurton-Jones, S.W.Rhee, D.H.Cribbs, C.W.Cotman, N.L.Jeon, A microfluidic culture platform for CNS axonal injury, regeneration and transport. Nature methods 2005; 2(8): 599-605.

42) J.Erickson, A.Tooker, Y.C.Tai, J.Pine, Caged neuron MEA: a system for long-term investigation of cultured neural network connectivity. Journal of neuroscience methods 2008; 175(1): $1-16$.

43) M.Masafumi, S.Linards, H.Hideo, O.Tohru, Photochemical processes induced by $157-\mathrm{nm}$ light in $\mathrm{H}(2)$-impregnated glassy $\mathrm{SiO}(2)$ :OH. Optics letters 1999; 24(13): 863-865.

44) M.Okoshi, M.Murahara, Area-selective nucleation of copper on fluorocarbon-resin surface using $\mathrm{ArF}$ excimer laser-induced chemical modification. Applied Physics Letters 1998; 72(20): 2616-2618. 